\title{
Dampak Pembelajaran Fisika Dengan Model Discovery Learning Menggunakan Metode One Minute Paper Terhadap Hasil Belajar Dan Keterampilan Proses Sains
}

\author{
Lia Yulianti, Sri Fatmawati, Hadma Yuliani \\ Program Studi Tadris Fisika, Pendidikan Matematika dan Ilmu Pengetahuan Alam, Fakultas Tarbiyah \\ dan Ilmu Keguruan, Institut Agama Islam Negeri Palangka Raya \\ Email : liayulianti151013@gmail.com
}

\begin{abstract}
Abstrak
Penelitian ini bertujuan untuk mengkaji dampak penerapan model pembelajaran discovery learning menggunakan metode one minute paper terhadap hasil belajar pada aspek afektif, kognitif, psikomotorik, dan keterampilan proses sains peserta didik pada pembelajaran fisika yaitu pokok bahasan momentum dan impuls. Penelitian ini menggunakan metode eksperimen dengan model one-group pretest-posttest design dengan pengambilan sampel menggunakan sampling jenuh, sampel yang dipilih yaitu kelas X IPA. Penelitian ini dilaksanakan di MA Muslimat NU Palangka Raya pada bulan April sampai dengan Mei 2017. Instrumen yang digunakan adalah tes berupa essay dan lembar pengamatan. Hasil penelitian menunjukkan bahwa: (1) terdapat perbedaan yang signifikan hasil belajar kognitif ; psikomotorik sebelum dan sesudah menggunakan model discovery learning menggunakan metode one minute paper pada materi momentum dan impuls, (2) hasil belajar afektif menggunakan model discovery learning menggunakan metode one minute paper pada materi momentum dan impuls, pertemuan I mendapaatkan nilai rata-rata 65,00, pertemuan II mendapatkan nilai rata-rata 78,75 dan pertemuan III mendapatkan nilai 83,13 , (3) terdapat perbedaan yang signifikan keterampilan proses sains sebelum dan sesudah menggunakan model discovery learning menggunakan metode one minute paper pada materi momentum dan impuls (4) terdapat hubungan yang signifikan keterampilan proses sains terhadap hasil belajar kognitif sebelum dan sesudah menggunakan model discovery learning dengan metode one minute paper pada materi momentum dan impuls.
\end{abstract}

Kata Kunci: model discovery learning, metode one minute paper hasil belajar kognitif, keterampilan proses sains

This study was aimed to study about the implementation of discovery learning model use the one minute paper method toward the students' learning outcomes at affective, cognitive, and psychomotorik aspects, and skill of science proses of students at main material of momentum dan impulse. This study used experiment method with one-group pretest-posttest design and sampling jenuh as the sample of this study, the class was X IPA MA Muslimat NU Palangka Raya on April until May 2017. The instrument that used were test essay and observational note. The result findings showed: 1) there was significant difference of learning outcomes of cognitive study result ; pyschomotor before and after use discovery learning model with one minute paper to material of momentum and impulse, (2) learning outcomes of affective by using discovery learning model with one minute paper at main material of momentum and impulse, first meeting showed mean score 65,00 , second meeting showed main score 78,75 and third meeting showed score 83,13, (3) there was significant difference to skill of science process before and after use discovery learning model with one minute paper at main material of momentum and impulse, (4) there was significant correlation between skill of science process toward learning outcomes of cognitive before and after use discovery learning model with one minute paper method at main material of momentum and impulse

Keyword: Discovery learning model, one minute paper learning cognitive, skill science process result.

\section{PENDAHULUAN}

Pendidikan adalah usaha yang terencana untuk dapat mewujudkan generasi penerus bangsa yang memiliki kualitas baik. Pendidikan merupakan proses pengubahan sikap atau perilaku untuk mendewasakan generasi penerus bangsa melalui sebuah pengajaran. Pendidikan adalah usaha sadar dan terencana untuk mewujudkan suasana belajar 


\section{JPSP: Jurnal Penelitian Sains dan Pendidikan}

https://e-journal.iain-palangkaraya.ac.id/index.php/mipa/

dan proses pembelajaran agar peserta didik secara aktif mengembangkan potensi dirinya untuk memiliki kekuatan spiritual, keagamaan, pengendalian diri, kepribadian akhlak mulia, serta keterampilan yang diperlukan dirinya, masyarakat, bangsa dan Negara (Rochaeti dkk., 2005).

Pembelajaran adalah proses dari belajar mengajar yang dilaksanakan dalam bidang pendidikan yang mana terdapat suatu ilmu pengetahuan, wawasan dan informasi yang diserap oleh otak kita dan juga berfungsi untuk memperoleh kembali informasi yang telah kita dapatkan. Belajar tidak hanya dilaksanakan atau dilakukan di sekolah saja, tetapi juga dapat dilakukan dimanapun dan dengan siapa pun yang mempunyai ilmu pengetahuan lebih banyak. Proses belajar mengajar, seorang guru harus bisa membuat suasana pembelajaran dalam kelas menyenangkan untuk peserta didik, agar menciptakan suasana pembelajaran yang nyaman, tidak terlalu tegang dan tidak terlalu santai. Tercapainya tujuan pembelajaran tergantung terhadap pembawaan seorang guru dalam mengajar (Druckman dan Eibner, 2017).

Fisika merupakan sebuah proses yang berkaitan fenomena atau peristiwa yang ada di lingkungan sehari-hari. Mata pelajaran fisika adalah salah satu mata pelajaran rumpun sains yang dapat mengembangkan kemampuan berpikir analitis induktif dan deduktif dalam menyelesaikan masalah yang berkaitan dengan peristiwa alam sekitar, baik secara kualitatif maupun kuantitatif. Pembelajaran fisika tidak hanya mengukur hasil belajar kognitifnya saja, fisika sebagai proses hendaknya juga dapat mengembangkan keterampilan proses sains pada diri peserta didik. Pembelajaran fisika dilaksanakan dengan membuktikan sebuah konsep melalui percobaan, sehingga keterampilan proses sains dibutuhkan dalam pembelajaran fisika. Keterampilan proses sains dibagi dalam dua bagian, yaitu keterampilan proses sains dasar dan keterampilan proses sains integrasi. Fisika berkaitan dengan cara mencari tau tentang fenomena alam secara sistematis sehingga fisika bukan hanya penguasaan kumpulan pengetahuan yang berupa fakta-fakta, konsep-konsep atau prinsip-prinsip saja tetapi juga merupakan suatu proses penemuan. Proses pembelajaran fisika menekankan pada pemberian pengalaman langsung untuk mengembangkan kompetensi agar peserta didik menjelajahi dan memahami alam sekitar secara ilmiah. Pembelajaran fisika diarahkan untuk mencari tau dan berbuat sehingga dapat membantu peserta didik memperoleh pemahaman yang mendalam tentang alam sekitar (Sururi 2016).

Model pembelajaran adalah salah satu alternatif yang membantu tercapainya tujuan pembelajaran. Maka dari itu seorang guru harus dapat memilih model pembelajaran yang tepat agar peserta didik dapat berperan aktif dalam proses pembelajaran dan tercapainya tujuan pembelajaran. Salah satu model yang dapat dijadikan referensi untuk membantu atau mengembangkan keaktifan peserta didik dalam belajar adalah model discovery learning. Model discovery learning menuntut peserta didik untuk dapat belajar secara mandiri sehingga membuat peserta didik ikut berperan aktif dalam pembelajaran. Model ini 


\section{JPSP: Jurnal Penelitian Sains dan Pendidikan}

https://e-journal.iain-palangkaraya.ac.id/index.php/mipa/

juga dapat melatih keterampilan peserta didik dalam belajar khususnya pada pembelajaran fisika.

Peserta didik didalam discovery learning, didorong untuk belajar sendiri secara mandiri. Berdasarkan fakta dan hasil pengamatan, penerapan pembelajaran penemuan memiliki kelebihan-kelebihan membantu peserta didik untuk memperbaiki dan meningkatkan keterampilan dan proses kognitif. Usaha penemuan merupakan kunci dalam proses ini, tergantung bagaimana cara belajarnya. Pengetahuan yang diperoleh sangat pribadi dan ampuh karena menguatkan pengertian, ingatan dan transfer. Menimbulkan rasa senang pada peserta didik, karena membangkitkan keingintahuan peserta didik, memotivasi peserta didik untuk bekerja terus sampai menemukan jawaban (Erlidawati dan Habibati, 2020).

Model pembelajaran juga dapat disandingkan dengan sebuah metode, agar dapat lebih membantu untuk meningkatkan keaktifan peserta didik dalam proses belajar, sehingga tercapainya tujuan pembelajaran. Salah satu metode yang dapat membantu peserta didik aktif dalam kegiatan belajar mengajar adalah metode one minute paper. Metode ini adalah metode kertas satu menit, teknik ini diberikan pada awal pertemuan sebelum memasuki materi pelajaran, yang bertujuan untuk mengetahui pengetahuan awal peserta didik. Pertanyaan yang diberikan hanya pertanyaan yang sederhana yang tidak memerlukan waktu yang lama untuk menjawabnya. Batas waktu peserta didik untuk menjawab pertanyaan adalah satu menit, paling lama diberikan waktu selama dua menit (Widiadnyana 2014).

Metode one minute paper adalah sebuah teknik pembelajaran aktif yang digunakan oleh guru untuk memberikan variasi pengajaran agar lebih efektif dengan menggunakan satu kertas yang berisi pertanyaan untuk dijawab oleh peserta didik (Warsono dan Hariyanto, 2012).

Titik sentral setiap pembelajaran terletak pada suksesnya peserta didik mengorganisasikan pengalamannya, dan kemampuan berpikir. Hasil angket respon peserta dikelas X IPA semester II di MA Muslimat NU yang berjumlah 44 orang terkait dengan mata pelajaran fisika menunjukkan $80 \%$ peserta didik tertarik dengan mata pelajaran fisika dan $20 \%$ peserta didik tidak tertarik pada pelajaran fisika. Dari hasil persentasi yang di dapat melalui angket yang telah disebar di MA Muslimat NU, penelitian ini membuat peserta didik yang tidak tertarik dengan pembelajaran fisika agar dapat tertarik seperti beberapa teman-temannya yang lain, agar tidak adanya peserta didik yang tidak memahami dan tidak mengerti pelajaran fisika. Pada model pembelajaran discovery learning, $62,5 \%$ peserta didik mengetahui dan menyukai bahwa model pembelajara tersebut dapat membuat mereka lebih aktif dalam pembelajaran fisika, dan $37,5 \%$ peserta didik tidak mengetahui dan tidak menyukai model pembelajaran tersebut, $35 \%$ peserta didik menjawab bahwa model tersebut menjenuhkan dan $65 \%$ peserta didik mejawab tidak membosankan. Di sekolah MA Muslimat NU juga jarang sekali melakukan praktikum atau 


\section{JPSP: Jurnal Penelitian Sains dan Pendidikan}

https://e-journal.iain-palangkaraya.ac.id/index.php/mipa/

percobaan langsung untuk membuktikan suatu konsep materi. Pembelajaran yang dilakukan dengan metode ceramah, yang titik fokus peserta didik hanya pada mendengarkan, tidak mempraktikannya secara langsung.

Berdasarkan permasalahan tersebut, model pembelajaran discovery learning diharapkan dapat diterapkan di sekolah tersebut sesuai dengan harapan peserta didik dapat lebih tertarik dan aktif ketika menggunakan model pembelajaran discovery learning. Model pembelajaran discovery learning lebih menekankan peserta didik untuk dapat menemukan dan melakukan percobaan secara mandiri namun tetap dalam bimbingan guru yang mengajar. Pada model pembelajaran discovery learning, peserta didik diberikan permasalahan awal, pada permasalahan tersebut materi pembelajaran fisika di ajarkan melalui eksperimen, dimana peserta didik tidak hanya mendapatkan teorinya saja tetapi juga membuktikan teori tersebut melalui eksperimen. Keinginan mengubah pola pikir peserta didik yang tidak tertarik pada materi pembelajaran fisika, agar mutu pedidikan di sekolah terkhususkan pada materi fisika dapat membaik dan meningkat dengan hasil belajar yang baik. Dalam model pembelajaran discovery learning ini disandingkan dengan metode belajar one minute paper dimana teknik ini merupakan teknik untuk mengukur kemajuan pembelajaran para peserta didik, baik kemajuan dalam pemahaman terhadap bahan ajar maupun kemajuan dalam melakukan tanggapan terhadap bahan ajar.

Pemilihan model pembelajaran discovery learning adalah salah satu alternatif solusi agar peserta didik yang mempelajari fisika mempunyai keterampilan proses sains dan pembelajaran pada materi momentum dan impuls sesuai dengan kompetensi dasarnya. Model pembelajaran Discovery learning diantaranya adalah model pembelajaran berbasis masalah dengan cara bereksperimen.

Kenyataan-kenyataan tersebut sangat mendorong untuk mengadakan penelitian, yang kemudian dituangkan dalam bentuk skripsi dengan judul Penerapan Model Discovery learning menggunakan Metode One Minute Paper Terhadap Hasil Belajar Dan Keterampilan Proses Sains Peserta didik Pada Pokok Bahasan Momentum Dan Impuls.

\section{METODE PENELITIAN}

Jenis penelitian ini adalah preexperimental designs. Desain penelitian yang digunakan dalam penelitian ini adalah satu kelompok pretes-posttes (OneGroup Pretest-Posttest Design). Pada desain ini terdapat pretest sebelum diberi perlakuan dan posttes setelah diberi perlakuan (Sugiono, 2008:14).

\begin{tabular}{ccc}
\hline Pre-test & Perlakuan & Posttest \\
\hline $\mathrm{Y}_{1}$ & $\mathrm{X}$ & $\mathrm{Y}_{2}$ \\
\hline
\end{tabular}

\section{Keterangan:}

$\mathrm{Y}_{1}$ : Pemberian tes sebelum materi diberikan

$\mathrm{Y}_{2}$ : Pemberian tes setelah materi selesai diberikan

$\mathrm{X}: \quad$ Perlakuan (dengan model
pembelajaran discovery learning dengan
menggunakan metode one minute paper)




\section{JPSP: Jurnal Penelitian Sains dan Pendidikan}

https://e-journal.iain-palangkaraya.ac.id/index.php/mipa/

Teknik pengumpulan data yang digunakan dalam penelitian ini antara lain dengan cara dokumentasi, observasi, dan tes. Instrumen penelitian yang digunakan berupa tes keterampilan proses sains peserta didik, tes hasil belajar kognitif dan keterampilan proses sains peserta didik, lembar pengamatan hasil belajar psikomotorik, dan lembar pengamatan hasil belajar afektif.

Analisis data penelitian ini terdiri dari dua tahap yaitu analisis data tahap awal dan tahap akhir. Pada tahap awal dilakukan uji homogenitas, uji normalitas dan uji linearitas. Sedangkan analisis tahap akhir menggunakan uji-t independent samples $T$ test 2-tailed atau uji mann whitney U-test untuk menganalisis perbedaan, dan uji korelasi product moment atau uji korelasi spearman untuk menganalisis hubungan dengan bantuan SPSS 21.

\section{HASIL DAN PEMBAHASAN}

\section{Uji Analisis Perbedaan Hasil Belajar}

\section{Kognitif Peserta Didik}

\section{a. Hasil Belajar Kognitif}

Rekapitulasi nilai rata-rata pretest, posttest, gain, dan $\mathrm{N}$-gain hasil belajar kognitif untuk kelas $\mathrm{X}$ IPA secara lengkap dapat ditunjukkan pada tabel 1 .
Tabel 1. Nilai Rata-rata Pretest, Posttest,

Gain, dan N-Gain Hasil Belajar Kognitif

\begin{tabular}{|c|c|c|c|c|}
\hline \multirow{2}{*}{ Kelas } & \multicolumn{4}{|c|}{ Rata-tata } \\
\hline & Pretest & Posttest & Gain & $N$-Gain \\
\hline X IPA & $41 \quad 21,67$ & 58,27 & 36,60 & 0,47 \\
\hline
\end{tabular}

Pada kelas X IPA yang diikuti 41 peserta didik sebelum diberi pembelajaran dengan model discovery learning menggunakan metode one minute paper, terlebih dahulu dilakukan pretest yang bertujuan untuk mengetahui pengetahuan awal peserta didik. Hasil belajar kognitif pretest diperoleh skor rata-rata keseluruhan 21,67. Hasil rata-rata posttest hasil belajar kognitif peserta didik setelah menggunakan model pembelajaran discovery learning menggunakan metode one minute paper diperoleh skor rata-rata keseluruhan 58,27. Hasil rata-rata gain sebesar 36,60 dan hasil rata-rata $\mathrm{N}$-gain sebesar 0,47.

Uji Hipotesis terdapat tidaknya perbedaan hasil belajar kognitif peserta didik kelas X IPA pada pokok bahasan momentum dan impuls menggunakan uji statistik parametrik yaitu uji $\mathrm{t}$ Independent-Samples $T$ Test untuk data yang berdistribusi normal dan homogen, sedangkan data yang berdistribusi tidak normal dan tidak homogen menggunakan uji non-parametrik yaitu uji mann-whitney $U$-test dengan kriteria pengujian apabila nilai signifikansi $>0,05$ maka Ho diterima dan Ha ditolak, sedangkan jika signifikansi $<0,05$ maka Ha diterima dan Ho ditolak. Hasil uji beda data pretest dan posttest, hasil belajar kognitif peserta didik pokok bahasan momentum dan impuls dapat dilihat pada tabel 2 . 


\section{JPSP: Jurnal Penelitian Sains dan Pendidikan}

https://e-journal.iain-palangkaraya.ac.id/index.php/mipa/

Tabel 2. Hasil Uji Beda Data Hasil Belajar

Kognitif

\begin{tabular}{llll}
\hline No & $\begin{array}{c}\text { Perhitungan } \\
\text { Hasil Belajar } \\
\text { Kognitif }\end{array}$ & Sig* & Keterangan \\
\hline 1. & Independent - & 0,000 & Terdapat \\
& Sample T Test & & perbedaan \\
& & & signifikan \\
& & &
\end{tabular}

*level signifikan 0.05

Tabel 2 menunjukkan bahwa hasil uji beda hasil belajar kognitif peserta didik diperoleh Asymp. Sig ( 2-tailed) sebesar 0,00 karena Asymp. Sig ( 2-tailed) <0,05 maka Ha diterima dan Ho ditolak yang berarti terdapat perbedaan yang signifikan hasil belajar kognitif peserta didik sebelum dan setelah pembelajaran. Hasil uji Independent -Sample T Test menunjukkan bahwa terdapat keberhasilan peningkatan hasil belajar kognitif peserta didik menggunakan model pembelajaran Discovery learning menggunakan metode One Minute Paper.

Pencapaian peningkatan hasil belajar kognitif peserta didik tidak tercapai secara maksimal. Hal ini dikarenakan pada saat proses pembelajaran sebagian peserta didik kurang memperhatikan apa yang disampaikan oleh guru. Banyaknya peserta didik dalam satu ruangan yang sempit sehingga kesulitan guru untuk berjalan dikelas agar dapat mengatur peserta didik yang kurang memperhatikan. Konsentrasi belajar peserta didik kurang fokus karena pembelajaran fisika di mulai menjelang siang hari. Hal ini sejalan dengan pernyataan Hanafiah yang menyatakan bahwa kelemahan dari model discovery learning (2012:79) yaitu, peserta didik harus memiliki kesiapan dan kematangan mental, peserta didik harus berani dan berkeinginan untuk mengetahui keadaan sekitarnya dengan baik. Jumlah peserta didik yang banyak di kelas dapat menyebabkan penggunaan model discovery learning tidak mencapai hasil yang memuaskan.

Banyaknya peserta didik dalam kelas $\mathrm{X}$ IPA yaitu, sebanyak 41 peserta didik sehingga membuat pencapaian keberhasilan peserta didik kurang maksimal. Walaupun keberhasilan peningkatan hasil belajar kognitif peserta didik kurang maksimal, tetapi model pembelajaran discovery learning menggunakan metode one minute paper mampu meningkatkan hasil belajar kognitif peserta didik. Hal ini sejalan dengan yang dikemukakan (Illahi, 2012:70) model discovery learning ini mempunyai kelebihan yaitu membangkitkan motivasi belajar karena peserta didik dilibatkan secara aktif dalam proses pembelajaran dan memecahkan permasalahan secara langsung dengan melakukan percobaan.

\section{b. Hasil Belajar Psikomotorik}

Rekapitulasi nilai rata-rata pretest, posttest gain, dan $N$-gain hasil belajar psikomotorik untuk kelas X IPA secara lengkap dapat ditunjukkan pada tabel 3.

Tabel 3. Nilai Rata-rata Pretest, Posttest, Gain, dan N-Gain Hasil Belajar Psikomotorik

\begin{tabular}{llllll} 
Kelas & N & \multicolumn{4}{c}{ Rata-rata } \\
& & Pretest & Posttest & Gain & N-Gain \\
& & & & & \\
\hline X IPA & 41 & 59,58 & 81,36 & 21,78 & 0,44 \\
\hline
\end{tabular}




\section{JPSP: Jurnal Penelitian Sains dan Pendidikan}

https://e-journal.iain-palangkaraya.ac.id/index.php/mipa/

Pada kelas X IPA yang diikuti 41 peserta didik sebelum diberi pembelajaran dengan model discovery learning menggunakan metode one minute paper, terlebih dahulu dilakukan pretest yang bertujuan untuk mengetahui pengetahuan awal peserta didik. Hasil belajar psikomotorik pretest diperoleh skor rata-rata keseluruhan 59,58. Hasil ratarata posttest hasil belajar psikomotorik peserta didik setelah menggunakan model pembelajaran discovery learning menggunakan metode one minute paper diperoleh skor rata-rata keseluruhan 81,36. Hasil rata-rata gain sebesar 21,78 dan hasil rata-rata $\mathrm{N}$-gain sebesar 0,44 .

Uji Hipotesis terdapat tidaknya perbedaan hasil belajar psikomotorik peserta didik kelas X IPA pada pokok bahasan momentum dan impuls menggunakan uji statistik parametrik yaitu uji t Independent-Samples T Test untuk data yang berdistribusi normal dan homogen, sedangkan data yang berdistribusi tidak normal dan tidak homogen menggunakan uji non-parametrik yaitu uji Mann-Whitney U-test dengan kriteria pengujian apabila nilai signifikansi > 0,05 maka Ho diterima dan Ha ditolak, sedangkan jika signifikansi $<0,05$ maka Ha diterima dan Ho ditolak. Hasil uji beda data pretest dan posttest, hasil belajar psikomotorik peserta didik pokok bahasan momentum dan impuls dapat dilihat pada tabel 4.
Tabel 4. Hasil Uji Beda Data Hasil Belajar Psikomotorik

\begin{tabular}{ccc}
\hline $\begin{array}{c}\text { Perhitungan } \\
\text { Hasil Belajar }\end{array}$ & & \\
Psikomotorik & & \\
\hline Mann-Whitney $U$ & 0,000 & Terdapat \\
& & perbedaan \\
& & signifikan \\
\end{tabular}

*level signifikan 0.05

Tabel 4 menunjukkan bahwa hasil uji beda hasil belajar psikomotorik peserta didik diperoleh Asymp. Sig ( 2-tailed) sebesar 0,000 karena Asymp. Sig ( 2-tailed) <0,05 maka Ha diterima dan Ho ditolak yang berarti terdapat perbedaan yang signifikan hasil belajar psikomotorik peserta didik sebelum dan setelah pembelajaran. Hasil uji Mann-Whitney $U$ menunjukkan bahwa terdapat keberhasilan peningkatan hasil belajar psikomotorik peserta didik menggunakan model pembelajaran Discovery learning dengan metode One Minute Paper.

Hasil dari penelitian ini untuk aspek psikomotorik dilihat dari nilai pretest dan postest yang didapatkan. Nilai dari pretest dan postest mengalami peningkatan yang berarti terdapat keberhasilan untuk meningkatkan hasil belajar psikomotorik menggunakan model discovery learning menggunakan metode one minute paper. Zulhelmi (13:2009) menyatakan bahwa model discovery learning sangat menunjang keberhasilan proses pembelajaran psikomotor adalah perasaan senang untuk belajar sains fisika (95\%) melalui penemuan terbimbing. Dari hasil analisis data diperoleh daya serap rata-rata 


\section{JPSP: Jurnal Penelitian Sains dan Pendidikan}

https://e-journal.iain-palangkaraya.ac.id/index.php/mipa/

hasil belajar psikomotor siswa 92,03\% pada kategori amat baik. Ketuntasan belajar siswa klasikal 100\% tuntas dan ketuntasan materi pelajaran psikomotor $100 \%$ tuntas. Hasil penelitian tersebut dapat dinyatakan bahwa pembelajaran sains fisika melalui penerapan pendekatan penemuan terbimbing sangat efektif.

\section{Hasil Belajar Afektif}

Hasil belajar afektif peserta didik pada kelas $\mathrm{X}$ IPA dinilai melalui lembar pengamatan yang diamati oleh empat orang pengamat yaitu mahasiswa dari IAIN Palangka Raya. Keempat pengamat ini merupakan asisten laboratorium dimana pengamat memberikan tanda $(\sqrt{ })$ pada lembar pengamatan sesuai dengan kriteria penilaian yang ditetapkan. Keempat pengamat melakukan pengamatan terhadap sikap (afektif) peserta didik dalam melaksanakan kegiatan pembelajaran dengan menggunakan instrumen lembar pengamatan sikap peserta didik. Selanjutnya dalam melakukan percobaan, peserta didik dibagi menjadi delapan kelompok. Satu orang pengamat, mengamati dua kelompok tetapi hanya satu kelompok yang dijadikan sampel pengamatan sikap peserta didik. Pengamatan dilakukan kepada empat kelompok peserta didik yang terdiri dari lima orang peserta didik. Berdasarkan data yang diperoleh pada kelas X IPA peserta didik berjumlah 41 orang dan diambil 20 peserta didik sebagai sampel. Presentase nilai rata-rata hasil belajar afektif peserta didik dapat dilihat pada tabel 5 .
Tabel 5. Hasil Rata-Rata Belajar Afektif Tiap Pertemuan Kelas X IPA

\section{Rata-rata}

Kelas N Pertemuan Pertemuan Pertemuan

\begin{tabular}{ccccc} 
& & I & II & III \\
\hline X IPA & 41 & 65,00 & 78,75 & 83,13 \\
\hline
\end{tabular}

Tabel 5 merupakan nilai rata-rata hasil belajar afektif kelas X IPA tiap pertemuan yang mnunjukkan bahwa nilai presentase ratarata peertemuan. Pertemuan pertama memperoleh nila 65,00 dengan kategori cukup baik, pada pertemuan kedua memperoleh nilai 78,77 dengan kategori baik dan pertemuan ketiga memperoleh nilai 83,13 dengan kategori baik. Hal ini menunjukkan bahwa peserta didik yang diambil sebagai sampel mengalami peningkatan hasil belajar afektif. Dari data tersebut dapat dikatakan bahwa ratarata hasil belajar peserta didik aspek afektif untuk tiap data pengamatan pada setiap pertemuan mengalami peningkatan. Peningkatan terbesar terlihat pada data hasil pengamatan III yaitu $83,13 \%$ berkategori baik. Hal ini sejalan dengan penelitian Zulhelmi (13:2009) menyatakan bahwa hasil belajar afektif berkategori baik ini dapat terjadi karena melalui pembelajaran penemuan terbimbing yang memberikan peluang yang luas kepada peserta didik untuk berkreativitas dalam pembelajaran dikelas sehingga dapat meningkatkan hasil belajar afektif. 


\section{JPSP: Jurnal Penelitian Sains dan Pendidikan}

https://e-journal.iain-palangkaraya.ac.id/index.php/mipa/

\section{Uji Analisis Perbedaan Keterampilan}

\section{Proses Sains Peserta Didik}

Rekapitulasi nilai rata-rata pretest, posttest, gain, dan N-gain Keterampilan Proses Sains untuk kelas X IPA secara lengkap dapat ditunjukkan pada tabel 6 .

Tabel 6. Nilai Rata-rata Pretest dan Posttest Keterampilan Proses Sains

\begin{tabular}{cccccc}
\hline Kelas & $\mathbf{N}$ & \multicolumn{3}{c}{ Rata-rata } \\
& & Pretest & Posttest & Gain & N-Gain \\
& 41 & 17,67 & 57,45 & 39,78 & 0,48 \\
\hline X IPA & 41 &
\end{tabular}

Pada kelas X IPA yang diikuti 41 peserta didik sebelum diberi pembelajaran dengan model discovery learning menggunakan metode one minute paper, terlebih dahulu dilakukan pretest yang bertujuan untuk mengetahui pengetahuan awal peserta didik. Keterampilan proses sains pretest diperoleh skor rata-rata keseluruhan 17,67. Hasil ratarata posttest keterampilan proses sains peserta didik setelah menggunakan model pembelajaran discovery learning menggunakan metode one minute paper diperoleh skor rata-rata keseluruhan 57,45. Hasil rata-rata gain sebesar 39,78 dan hasil rata-rata $\mathrm{N}$-gain sebesar 0,48 .

Uji Hipotesis terdapat tidaknya perbedaan keterampilan proses sains peserta didik kelas X IPA pada pokok bahasan momentum dan impuls menggunakan uji statistik parametrik yaitu uji t Independent-Samples T Test untuk data yang berdistribusi normal dan homogen, sedangkan data yang berdistribusi tidak normal dan tidak homogen menggunakan uji non-parametrik yaitu uji mann-whitney U-test dengan kriteria pengujian apabila nilai signifikansi > 0,05 maka Ho diterima dan $\mathrm{Ha}$ ditolak, sedangkan jika signifikansi $<0,05$ maka Ha diterima dan Ho ditolak. Hasil uji beda data pretest dan posttest, keterampilan proses sains peserta didik pokok bahasan momentum dan impuls dapat dilihat pada tabel 7.

Tabel 7. Hasil Uji Beda Data Keterampilan Proses Sains

\begin{tabular}{ccc}
\hline $\begin{array}{c}\text { Perhitungan } \\
\text { Keterampilan Proses } \\
\text { Sains }\end{array}$ & & \\
\hline Independent-Samples T & 0,000 & Terdapat \\
Test & & perbedaan \\
& & signifikan
\end{tabular}

*level signifikan 0.05

Tabel 7 menunjukkan bahwa hasil uji beda keterampilan proses sains peserta didik diperoleh Asymp. Sig ( 2-tailed) sebesar 0,000 karena Asymp. Sig ( 2-tailed) <0,05 maka Ha diterima dan Ho ditolak yang berarti terdapat perbedaan yang signifikan hasil belajar psikomotorik peserta didik sebelum dan setelah pembelajaran. Hasil uji IndependentSamples $T$ Test menunjukkan bahwa terdapat keberhasilan peningkatan keterampilan proses sains peserta didik menggunakan model pembelajaran Discovery learning dengan metode One Minute Paper.

Dari nilai rata-rata pretest dan posttest keterampilan proses sains menunujukkan adanya perbedaan nilai. Hasil analisis yang ditunjukkan pada tabel 7 hasil pengujian Ho ditolak dan Ha diterima, karena Sig. 0,000 


\section{JPSP: Jurnal Penelitian Sains dan Pendidikan}

https://e-journal.iain-palangkaraya.ac.id/index.php/mipa/

lebih kecil dari nilai 0,05 . Hal ini menunjukan bahwa antara pretest yang diuji sebelum menggunakan penerapan model pembelajaran discovery learning menggunakan metode one minute paper dan posttest yang diuji sesudah menggunakan penerapan model pembelajaran discovery learning menggunakan metode one minute paper, ternyata memiliki perbedaan yang signifikan, yang berarti adanya keberhasilan peningkatan keterampilan proses sains peserta didik setelah menggunakan model pembelajaran discovery learning menggunakan metode one minute paper.

Pencapaian peningkatan keterampilan proses sains peserta didik tidak tercapai secara maksimal. Hal ini dikarenakan pada saat proses pembelajaran sebagian peserta didik kurang memperhatikan apa yang disampaikan oleh guru, dan dalam melakukan penyelidikan sebagian peserta didik hanya melihat tanpa terlibat langsung dalam pengambilan data serta peserta didik masih dalam proses untuk membiasakan diri menerima soal-soal yang memiliki aspek keterampilan proses sains terintegrasi. Selain itu dalam melakukan percobaan sebagian peserta didik hanya mengerjakan apa yang ada di dalam lembar kerja peserta didik (LKPD) tanpa memahami makna dari percobaan itu sendiri yang sebenarnya berhubungan dengan materi yang dipelajari dan soal yang mereka kerjakan pada saat posttest. Sehingga mengakibatkan pencapaian peningkatan keberhasilan keterampilan proses sains peserta didik kurang maksimal. Hasil analisis dari keterampilan proses sains sejalan dengan hasil penelitian Kumalasari (2015) bahwa penerapan model discovery learning pada keterampilan proses sains peserta didik pada kelas eksperimen yang menggunakan model discovery learning lebih baik daripada keterampilan proses sains peserta didik pada kelas kontrol yang tidak menggunakan model discovery learning.

\section{Uji Analisis Hubungan Keterampilan} Proses Sains Terhadap Hasil Belajar Kognitif Peserta Didik

Berdasarkan hasil penelitian, hasil belajar kognitif dan keterampilan proses sains peserta didik menggunakan model Discovery learning menggunakan metode One Minute Paper pada kelas X IPA.

Uji hipotesis terdapat atau tidak terdapat hubungan hasil belajar kognitif peserta didik dengan keterampilan proses sains pokok bahasan momentum dan impuls pada kelas $\mathrm{X}$ IPA menggunakan uji statistik parametik yaitu uji Korelasi Pearson Produk Moment untuk data yang berdistribusi normal dan linear, sedangkan data yang tidak berdistribusi normal dan tidak linear menggunakan uji nonparametrik yaitu uji Korelasi Spearmen. Kriteria pengujian nilai signifikansi $<0,01$ berarti terdapat hubungan signifikan, sedangkan jika signifikansi > 0,01 berarti tidak terdapat hubungan signifikan. Hasil uji linearitas pada data pretest hasil belajar kognitif - pretest keterampilan proses sains dan postest hasil belajar kognitif - postest keterampilan proses sains pada kelas X IPA dapat dilihat pada tabel 8 . 


\section{JPSP: Jurnal Penelitian Sains dan Pendidikan}

https://e-journal.iain-palangkaraya.ac.id/index.php/mipa/

Tabel 8. Hasil Uji Kolerasi Kelas X IPA

\begin{tabular}{|c|c|c|c|c|c|}
\hline No. & $\begin{array}{c}\text { Perhitunga } \\
\text { Korelasi } \\
\text { Pearson }\end{array}$ & $\mathbf{r}_{\text {hitung }}$ & Kategori & Sig* & Keterangan \\
\hline $\begin{array}{l}1 \\
.\end{array}$ & $\begin{array}{l}\text { Pretest } \\
\text { Pretest } \\
\text { Hasil } \\
\text { Belajar - } \\
\text { KPS }\end{array}$ & 0,691 & Tinggi & 0,000 & $\begin{array}{c}\text { Terdapat } \\
\text { hubungan } \\
\text { yang } \\
\text { signifikan }\end{array}$ \\
\hline $\begin{array}{l}2 \\
\text {. }\end{array}$ & $\begin{array}{l}\text { Posttest } \\
\text { Posttest } \\
\text { Hasil } \\
\text { Belajar - } \\
\text { KPS }\end{array}$ & 0,557 & Cukup & 0,000 & $\begin{array}{l}\text { Terdapat } \\
\text { hubungan } \\
\text { yang } \\
\text { signifikan }\end{array}$ \\
\hline
\end{tabular}

Pada pretest hasil belajar kognitifketerampilan proses sains di dapatkan nilai yaitu 0,664, dengan kategori sangat tinggi dan nilai sig yang didapatkan yaitu 0,000 . Nilai sig yang didapat $<0,01$ yang berarti terdapat hubungan yang signifikan pretest hasil belajar kognitif-keterampilan proses sains pada kelas X IPA. Kemudian untuk data postest hasil belajar kognitif-keterampilan proses sains didapatkan nilai yaitu 0,441 dengan kategori sedang dan nilai sig yang didapatkan yaitu 0,000 . Nilai sig yang didapat $<0,01$ yang berarti terdapat hubungan yang signifikan postest hasil belajar kognitif-keterampilan proses sains pada kelas X IPA. Dari hasil analisis dapat disimpulkan bahwa Ha diterima dan Ho ditolak untuk pretest dan posttest keterampilan proses sains dan hasil belajar kognitif. Hal ini berarti bahwa "terdapat hubungan signifikan antara keterampilan proses sains terhadap hasil belajar kognitif setelah penerapan model pembelajaran discovery learning menggunakan metode one miunte paper" artinya keterampilan proses sains peserta didik pada kelas $X$ mempengaruhi hasil belajar kognitif untuk kelas tersebut.

Artinya, keterampilan proses sains mempengaruhi hasil belajar kognitif. Nilai hasil belajar kognitif tinggi maka keterampilan proses sains nya tinggi dan begitu pula sebaliknya. Terdapatnya hubungan keterampilan proses sains terahadap hasil belajar kognitif juga dinyatakan oleh Rahayu (2011) bahwa pendekatan keterampilan proses dapat meningkatkan hasil belajar peserta didik. Peserta didik dengan KPS tinggi mampu melakukan percobaan dengan baik. Dengan demikian, peserta didik lebih mudah dalam memahami materi yang diajarkan melalui pelaksanaan percobaan. Hal ini berdampak pada prestasi kognitif peserta didik yakni peserta didik dengan keterampilan proses sains tinggi akan memiliki prestasi kognitif yang lebih baik daripada peserta didik dengan keterampilan proses sains rendah.

\section{SIMPULAN}

Berdasarkan hasil penelitian maka dapat disimpulkan bahwa :

1. Analisis hipotesis hasil belajar kognitif peserta didik memperoleh nilai signifikan sebesar 0,000 lebih kecil dari nilai $\alpha$, yaitu 0,05 . Hal tersebut menunjukkan bahwa terdapat perbedaan yang signifikan antara hasil belajar kognitif peserta didik sebelum dan setelah perlakuan, maka Ho ditolak dan Ha diterima. Sedangkan, Analisis hipotesis hasil belajar psikomotorik peserta didik memperoleh nilai sig. sebesar 0,000 lebih kecil dari nilai $\alpha$, yaitu 0,05 . Hal tersebut 
https://e-journal.iain-palangkaraya.ac.id/index.php/mipa/

menunjukkan bahwa terdapat perbedaan yang signifikan antara hasil belajar psikomotorik peserta didik sebelum dan setelah perlakuan, maka Ho ditolak dan $\mathrm{Ha}$ diterima.

2. Analisis hipotesis keterampilan proses sains peserta didik memperoleh nilai signifikan sebesar 0,000 lebih kecil dari nilai $\alpha$, yaitu 0,05 . Hal tersebut menunjukkan bahwa terdapat perbedaan yang signifikan antara keterampilan proses sains peserta didik sebelum dan setelah perlakuan, maka Ho ditolak dan $\mathrm{Ha}$ diterima.

3. Hasil analisis data pretest hubungan antara keterampilan proses sains terhadap hasil belajar kognitif peserta didik yang menggunakan model discovery learning menggunakan metode one minute paper terlihat mengalami hubungan dengan nilai sebesar 0,691 termasuk dalam kategori tinggi sedangkan nilai signifikan sebesar 0,000 lebih kecil dari 0,01. Pada data postest hubungan antara keterampilan proses sains terhadap hasil belajar kognitif peserta didik yang menggunakan model discovery learning menggunakan metode one minute paper juga terlihat mengalami hubungan dengan nilai sebesar 0,557 termasuk dalam kategori cukup sedangkan nilai signifikan sebesar 0,000 lebih kecil dari 0,01, maka Ho ditolak dan $\mathrm{Ha}$ diterima.

4. Nilai rata-rata hasil belajar afektif untuk kelas X IPA untuk tiap pertemuan adalah $65,00,78,75$, dan 83,13 dimana hasil belajar afektif peserta didik pada kelas $\mathrm{X}$
IPA pada tiap pertemuan mengalami peningkatan.

\section{DAFTAR PUSTAKA}

Druckman D, Ebner N. 2017. Discovery learning in management education : design and case analysis. Journal of Management Education, 8(2):1-28

Erlidawati, Habibati. 2020. Penerapan model discovery learning untuk meningkatkan aktivitas dan hasil belajar peserta didik pada materi termokimia. Jurnal Pendidikan Sains Indonesia, 8(1):92-104

Kumalasari D. 2015. Dampak Model Discovery Learning Terhadap Keterampilan Proses Sains Dan Hasil Belajar ipa-Fisika Siswa Di Mts Negeri Jember 1. JURNAL PENDIDIKAN FISIKA (JPF). 5(1): 23-31.

Illahi TM. 2021. Pembelajaran Discovery Strategi Dan Mental Vacational Skill, Yogjakarta: DIVA PRESS.

Rochaeti E. 2005. Sistem Informasi Manajemen Pendidikan, Jakarta: Bumi Aksara.

Sugiyono. 2008. Metode Penelitian Pendidikan. Bandung: Alfabeta.

Warsono dan Hariyanto. 2012. Pembelajaran Aktif Teori Dan Asesmen. PT Remaja Rosdakarya; Bandung.

Widiadnyana I W. Sadia I W. Suastra I W. 2014. Pengaruh Model Discovery Learning Terhadap Pemahaman Konsep IPA Dan Sikap Ilmiah Siswa SMP. e-Journal Program Pascasarjana Universitas Pendidikan Ganesha. 4(2014): 1-10. 


\section{JPSP: Jurnal Penelitian Sains dan Pendidikan}

https://e-journal.iain-palangkaraya.ac.id/index.php/mipa/

Zuhelmi. 2009. Penilaian Psikomotorik Dan

Respon Siswa Dalam Pembelajaran Sains

Fisika Melalui Penerapan Penemuan
Terbimbing Di SMP Negeri Pekan Baru.

Jurnal Geliga Sains. 